
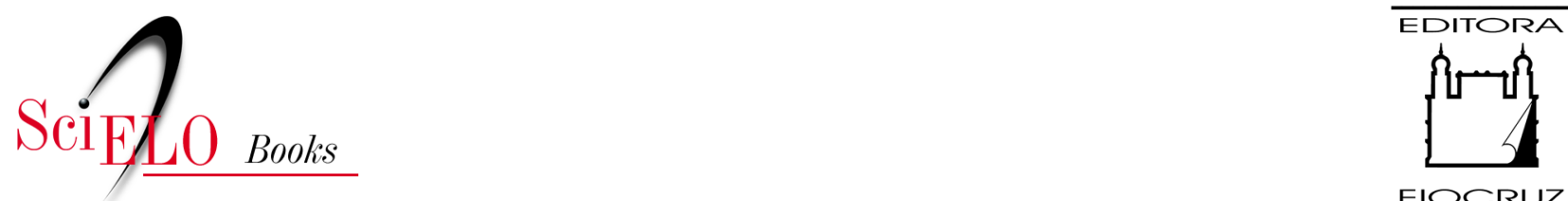

FIOCRUZ

\title{
Um pouco de história evolução das concepções de saúde, doença e cuidado
}

\author{
Gloria Regina da Silva e Sá \\ Omara Machado Araújo de Oliveira \\ Paula de Castro Nunes \\ Grácia Maria de Miranda Gondim
}

\section{SciELO Books / SciELO Livros / SciELO Libros}

SÁ, G.R.S., OLIVEIRA, O.M.A., NUNES, P.C., and GONDIM, G.M.M. Um pouco de história: evolução das concepções de saúde, doença e cuidado. In: SILVA, M.N., FLAUZINO, R.F., GONDIM, G.M.M., eds. Rede de frio: fundamentos para a compreensão do trabalho [online]. Rio de Janeiro: Editora FIOCRUZ, 2017, pp. 21-50. ISBN: 978-65-5708-091-7.

https://doi.org/10.7476/9786557080917.0003.

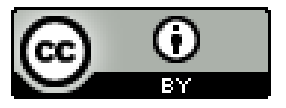

All the contents of this work, except where otherwise noted, is licensed under a Creative Commons Attribution 4.0 International license.

Todo o conteúdo deste trabalho, exceto quando houver ressalva, é publicado sob a licença $\underline{\text { Creative }}$ Commons Atribição 4.0.

Todo el contenido de esta obra, excepto donde se indique lo contrario, está bajo licencia de la licencia Creative Commons Reconocimento 4.0. 


\section{Um pouco de história: evolução das concepções de saúde, doença e cuidado}

Gloria Regina da Silva e Sá, Omara Machado Araújo de Oliveira, Paula de Castro Nunes e Grácia Maria de Miranda Gondim

Que tal iniciar os estudos com uma viagem de descobertas sobre as raízes históricas das concepções de saúde e doença? Nesse percurso, serão apresentados os elementos centrais para a organização de um novo modo de conceber o adoecimento humano. Para orientar esse trajeto, algumas indagações iniciais são fundamentais:

O que faz as pessoas adoecerem?

* Por que algumas pessoas adoecem e outras não, em situações semelhantes?

* Qual a razão ou explicação de certas doenças ocorrerem em determinados lugares?

Quais mecanismos fazem alguns eventos de saúde acontecerem em um dado período de tempo e, em outro, não?

* Por que as populações têm determinado perfil de saúde?

粶Por que certos problemas são predominantes em determinadas populações?

米 possível viver sem adoecer?

\section{Uma aproximação às concepções sobre saúde-doença ao longo da história}

A primeira reflexão que podemos fazer é que as respostas às questões sobre saúde e doença apenas serão possíveis se observarmos os contextos de vida dos indivíduos e dos coletivos humanos ao longo do tempo. 
Epidemiológica se refere à epidemiologia, um termo de origem grega. Em grego, epi significa sobre, demo significa população, e logia, estudo. Logo, epidemiologia significa estudo sobre população

O primeiro registro do emprego dessa expressão data de 1802, na Europa, na época das grandes epidemias. Entretanto, somente a partir do conhecimento sobre as doenças infectocontagiosas, durante o século XIX, a evolução do conhecimento epidemiológico avançou na perspectiva de identificar os mecanismos de transmissão das doenças e de controle de epidemias.

O conceito de risco, especialmente apropriado ao campo da vigilância em saúde, será abordado no Capítulo 3, "Introdução à vigilância em saúde: vigilância epidemiológica, vigilância sanitária, ambiental e saúde do trabalhador". Já o conceito de epidemiologia será discutido no Capítulo 4, "Conhecendo a epidemiologia".
São nesses lugares e situações que a vida transcorre e onde se dão as interações entre pessoas, ambientes e outros elementos biológicos, químicos e físicos.

Diariamente, vivenciamos, ouvimos ou assistimos a fatos relacionados à saúde e à doença que ocorrem em diferentes contextos, com riscos e vulnerabilidades presentes que se configuram como problemas locais, nacionais ou globais. Tais problemas desencadeiam ações e reações diversas na população, nos governos e nas instituições, que buscam explicá-los e resolvê-los considerando suas características epidemiológicas, políticas, econômicas e sociais.

Tudo isso aponta para a necessidade de se compreender e explicar os contextos nos quais os eventos de saúde-doença se desenvolvem, ou seja, o território. Só então será possível intervir sobre eles na perspectiva de proteger e promover a saúde dos indivíduos e dos coletivos humanos.

Para compreender o território, é preciso reconhecer que a humanidade, ao longo de sua história, constrói seus modelos explicativos, ou formas de conceber uma determinada situação, com base em sua organização social, econômica, política e cultural e no avanço das tecnologias. Esses avanços traduzem seu modo de pensar e agir.

Todo trabalhador da saúde deve conhecer como foram estruturadas as concepções de saúde, doença e cuidado ao longo da história. Isso ajuda não apenas a compreender as doenças e os agravos que ocorrem na população, mas, sobretudo, a refletir sobre a organização do processo de trabalho em saúde - em especial, do trabalho em rede de frio de imunobiológicos, destacando-se sua contribuição para a melhoria do estado de saúde da população.

Sabemos que o conjunto de trabalhadores vinculados à rede de frio de imunobiológicos é composto por profissionais que realizam uma gama de processos e ações visando à prevenção de doenças. Isso se dá por meio de imunizações, controle e monitoramento de microrganismos patogênicos em populações e territórios específicos, o que incide diretamente no estado de saúde e no cuidado às pessoas. Para formar trabalhadores com capacidade crítica para refletir, compreender e atuar sobre problemas (causa, riscos e danos) na perspectiva de intervir na realidade social e de saúde de populações, é preciso ter a concepção do processo saúde-doença como eixo estruturador da formação e do currículo.

Superar a visão reducionista de saúde como ausência de doença e a visão de educação profissional como mera repetição de técnicas e conteúdos 
para a realização de procedimentos por profissional de nível médio significa romper com a fragmentação do conhecimento (entre teoria e prática) e do processo de trabalho (entre quem formula e quem executa). Essa tarefa requer situar as dimensões histórica, social e cultural dos saberes, das concepções, dos modelos de atenção e do próprio trabalho, para buscar uma nova forma de agir no campo da saúde.

\section{Para refletir}

Em que situações do cotidiano do seu trabalho você percebe que está relacionando a teoria com a sua prática? De que forma essa relação se revela fundamental no encaminhamento de ações para a produção de saúde junto à população?

Embora tenhamos claro que trabalhar conceitos aparentemente se distancie da objetividade e concretude das práticas cotidianas dos serviços, é importante reafirmar que teoria e práticas de saúde estão fortemente vinculadas. É essa relação entre ambas que define as formas, os métodos, as estratégias, as ações e as tecnologias que devem ser utilizados para tratar dos corpos e orientar a vida das pessoas, bem como organizar os serviços de saúde.

Nesse âmbito, não há ordem nem consenso sobre qual delas orienta ou é impulsionada pela outra: se a teoria e seus conceitos baseiam as práticas, ou se estas produzem evidências, antecipam-se e impulsionam a teoria. O que se reconhece é a contribuição dessa interação para os resultados que se deseja alcançar - na seleção do conhecimento adequado, na escolha e no uso de métodos, técnicas e instrumentos para a intervenção e, por fim, na forma de organização da sociedade para produzir saúde ou afastar as chances de adoecimento (BARATA, 2005; BATISTELLA, 2006).

Em pleno século XXI, a ciência e a história nos brindam com uma concepção ampliada de saúde, a qual estabelece que os contextos e as determinações do adoecimento estão nas condições de existência das pessoas. Com base nessa concepção, nos questionam sobre como viabilizar a operacionalização das políticas de saúde, reforçando seu caráter multidimensional, transdisciplinar e intersetorial para a melhoria das condições de vida e saúde das populações frente à complexidade dos problemas e à frágil capacidade operacional das estruturas do Estado.

Temos um dilema! Resta-nos compreender, buscar respostas e construir novos questionamentos para poder avançar e continuar aprendendo. 


\section{As concepções místico-religiosas dos povos primitivos: xamãs, sacerdotes e curandeiros}

Os povos primitivos, ou da Pré-História, viviam em um tempo em que ainda não havia a forma escrita de comunicação, surgida somente por volta de 4000 a.C. Eles desenvolveram, porém, em seus estágios evolutivos (Paleolítico, Mesolítico e Neolítico), mesmo de forma rudimentar, um modo singular de se comunicar - uma linguagem, a qual possibilitou realizar grandes descobertas, como o uso da pedra para o corte e o fogo para aquecer. Esses domínios cognitivos e técnicos contribuíram para iniciar uma incipiente organização social e lhes permitiram deixar marcas e inscrições sobre seus modos de vida e suas concepções de mundo. Mesmo com os avanços proporcionados pela vida em comunidade, emergiam novos problemas e se acentuavam os males existentes em função das mudanças de habitus e estilos de vida (ROSEN, 1994).

Na fase Paleolítica, conhecida como o mais longo período da evolução da humanidade, entre 4 milhões e 10000 a.C. (BAZIN, 1976), o homem primitivo era nômade, mudava de lugar todas as vezes que, na natureza ao seu redor, terminava o estoque de alimentos, o qual era de propriedade e consumo coletivos. Esse movimento fez com que esses povos coletores não definissem um território específico para viver. Por isso, necessitavam buscar constantemente um abrigo para se proteger do frio, da chuva, do calor e das intempéries, e também para evitar o ataque de animais e outros agressores. Essa primeira preocupação com a sobrevivência está relacionada à saúde, à chance de preservar a vida e se manter saudável. A forma de se comunicar era rudimentar, por meio de uma linguagem baseada em poucos sons e palavras, e utilizavam pinturas feitas na pedra (rupestres) para trocar ideias, sentimentos e preocupações cotidianas.

O período Mesolítico, compreendido entre 10000 e 7500 a.C. (BAZIN, 1976), foi o início de grandes mudanças que iriam ocorrer na organização social. A descoberta do fogo aliada ao cultivo da terra, à produção de alimentos e à domesticação de animais permitiram a fixação do homem em sítios próximos de rios e vales férteis, dando origem aos primeiros aldeamentos. A domesticação dos animais, seja para auxílio no plantio, seja como fonte regular de proteínas, foi elemento crucial no aparecimento de novas doenças. O homem passou, desse modo, de nômade a agricultor e pastor, reduzindo sua dependência em relação à natureza. Ficou mais sedentário, pois tinha na habitação fixa uma necessidade. Esse fato possibilitou a divisão do trabalho por sexo, 
cabendo ao homem a proteção e o sustento das famílias e, à mulher, a criação dos filhos e o cuidado com a habitação.

No período Neolítico, compreendido entre 7500 e 5000 a. C. (BAZIN, 1976), o homem atingiu alto grau de desenvolvimento e estabilidade, com mudanças radicais em seus modos de viver. Um dos maiores avanços foi o desenvolvimento da metalurgia, possibilitando a criação de objetos de metais, como lanças e machados, dando maior agilidade à caça e à produção de alimentos e bens, com mais qualidade e rapidez. Desse modo, propiciava um excedente na produção agrícola, que, armazenado, garantia o alimento necessário em tempos de seca ou inundações. Esse fato permitiu o crescimento das comunidades e a troca intensiva entre pequenas cidades e vilas, aumentando a divisão de trabalho e originando o trabalho especializado.

Nesse longo período da história da humanidade, o contato permanente com a natureza e o trabalho desenvolvido com as mãos modularam a percepção desses povos sobre saúde e doença. Alguns microrganismos, originalmente presentes nos animais, pouco a pouco foram se adaptando e disseminando-se entre as populações humanas. Doenças como a varíola e a tuberculose migraram do gado para os seres humanos. Porcos e aves transmitiram a gripe, e o cavalo, o resfriado comum (PALMEIRA et al., 2004). O armazenamento de alimentos e a concentração dos dejetos nas aldeias aproximaram os vetores do convívio humano.

Tudo aquilo que não podia ser explicado com base no convívio imediato ou na acumulação de conhecimentos, como, por exemplo, a fadiga, o ferimento ou a queda decorrente de uma atividade, forjava explicações místicas (como se a situação fosse resultante da ação de demônios), visões místicas sobre esse novo tipo de acontecimento - a doença.

Assim, esses grupamentos humanos criavam entidades sobrenaturais que designavam como "Deuses" e que regiam a vida das pessoas e dos coletivos, a exemplo do vento, do fogo, do trovão e da floresta. Quando alguém contrariava a vontade de uma dessas entidades, surgiam adoecimento ou manifestações mórbidas no corpo do transgressor, que o faziam sair de seu estado normal, ou mesmo morrer.

A estrutura mágico-religiosa do pensamento possibilitou, em diferentes culturas, a coesão da vida social e o início do desenvolvimento das práticas de cura. Essas eram delegadas a pessoas iniciadas, que se tornavam líderes espirituais: os xamãs e pajés entre os índios brasileiros; o sacerdote entre os incas e astecas; as benzedeiras, curandeiros e sobas 
no continente africano. Suas funções e poderes apoiavam-se nas forças da natureza, por meio de rituais, mágica e reza, os quais se destinavam a conservar o elo sobrenatural com o universo.

Desse modo, realizavam a cura exortando o mal e restabelecendo a saúde do enfermo por meio de evocações de entidades, afastamento de espíritos malignos, cânticos, danças, instrumentos musicais, infusões, emplastros, plantas psicoativas, jejum, restrições dietéticas, reclusão, tabaco, calor, defumação, massagens, fricção, extração da doença por vômito, entre outros recursos terapêuticos (BATISTELLA, 2006; SCLIAR, 2002).

A intensificação do comércio e das trocas entre populações resultou do excedente gerado pelo aumento da produção agrícola, possibilitando mais contatos humanos, favorecendo a circulação de parasitos e a disseminação das doenças. À medida que as diferentes civilizações foram se desenvolvendo e se consolidando, surgiram outras formas de enfrentar os problemas de saúde. Esses fenômenos caracterizam o surgimento das civilizações antigas, com o advento da escrita em 4000 a.C.

\section{Os povos antigos e o pensamento racional greco-romano: ares, águas e lugares}

Há escavações feitas no norte da Índia que confirmam a existência de uma antiga civilização (5000 a 3000 a.C.), hoje identificada como uma das Civilizações Hidráulicas, assim chamadas por se situarem às margens de rios (Tigre e Eufrates, na Turquia, Síria e Iraque; Nilo, no Egito; Amarelo e Azul, na China; Ganges e Indo, na Índia). Ela já apresentava indícios de planejamento urbano, com ordenamento das casas, ruas largas, pavimentadas e canais para escoamento do esgoto.

Do mesmo modo, sistemas de abastecimento de água, instalações para banhos, descargas para lavatórios e canalização para o esgoto também estavam presentes no Antigo Egito (3100 a.C.), na cultura Creto-Micênica (1500 a.C.) e, bem mais adiante, entre os quéchuas, no Império Inca (1200 d.C.).

Esses achados demonstram que questões relacionadas com a limpeza do ambiente e com o corpo acompanham o homem há bastante tempo, motivadas por diferentes razões. Entre elas, a religiosidade é um marco que até hoje exerce influência nas formas de perceber a saúde e a doença (ROSEN, 1994). Por não conseguir explicar tudo na natureza, as concepções mágico-religiosas abriram espaço para a consolidação de um novo pensamento sobre a saúde e o adoecimento. Os gregos e seu 
modo de organização social romperam esse conjunto de saberes e práticas e buscaram explicações de forma mais racional.

Os métodos da medicina grega buscavam articular o culto aos deuses às práticas de curas por meio do uso de ervas e de métodos naturais. Os médicos daquela época procuravam associar os problemas de saúde aos processos naturais que os rodeavam, em vez de recorrerem à religiosidade. Essa forma de observar a natureza e seus movimentos ofereceu elementos importantes para a criação de um novo método para organizar o pensamento e explicar o adoecimento e a morte. A isso chamamos, hoje, de método observacional ou empírico.

Foi com Hipócrates (460-377 a.C.), chamado de pai da medicina, e sua obra que o pensamento racional tomou força, por meio do seu livro Ares, Águas e Lugares. Nesse texto científico, pela primeira vez, se conhece o termo endêmicas, para designar as doenças que permaneciam por muito tempo nas populações, com uma quantidade estável e contínua de casos. Atribuíam-se a esse fenômeno fatores relacionados ao lugar - o clima, a água, o solo, o modo de viver e a alimentação.

De forma semelhante, quando surgia com grande rapidez um número excessivo (explosivo) de casos de uma doença na população, Hipócrates denominava de epidemia. Esses dois comportamentos das doenças contribuíram (e contribuem até os nossos dias) para que as populações tomassem medidas para preveni-las. As ações de prevenção foram úteis para proteger as populações de doenças trazidas pela mobilidade de pessoas em decorrência da conquista de novos territórios.

A questão central da medicina grega era preservar o equilíbrio e a harmonia do corpo humano e sua relação com o meio. Toda prática racional de cura tinha como pressuposto essa preocupação, e

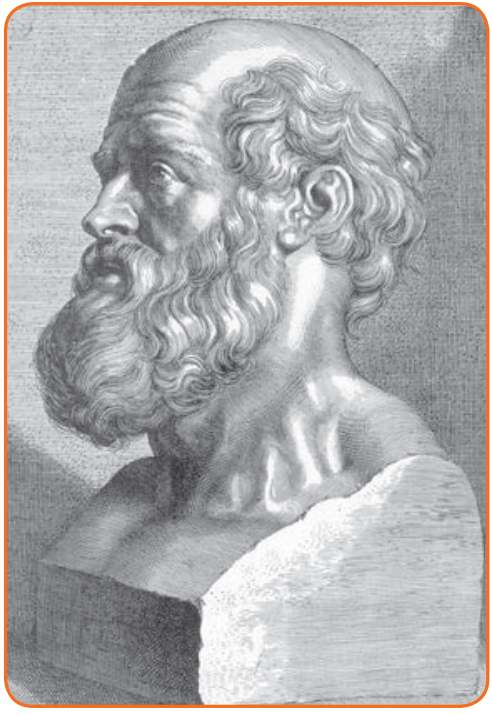

Hipócrates é considerado o pai da medicina, e o juramento que cunhou é realizado até os dias de hoje por quem inicia essa carreira.

Fonte: Wikimedia Commons. se recomendavam ações educativas e de higiene pessoal e coletiva para uma vida ideal. Para tanto, era fundamental observar as secreções e ter rigor com a alimentação, o descanso e a prática de exercício. Já naquela época, os médicos realizavam quatro passos fundamentais para tratar as pessoas: explorar o corpo (ausculta
Você sabia?

Na mitologia grega, havia uma entidade chamada Asclepíades, ou Asclépio, designada como deus da medicina e da cura. Ele teve duas filhas: a uma chamou de Panacea, tida como deusa da cura e significando remédio para todos os males, e a outra de Hygeia, de onde deriva a palavra higiene, alçada como deusa da saúde e da limpeza. A ambas Asclepíades ensinou sua arte de tratar, higienizar e curar.

\section{Você sabia?}

O termo malária tem origem em mala aria (maus ares), porque se acreditava que essa doença era causada pela presença de mau ar. $\mathrm{Na}$ época, sabia-se que as zonas pantanosas produziam gases e que as populações que habitavam esses locais facilmente adoeciam com malária. 
Miasma vem do grego miasma, mancha. Para Hipócrates, miasmas significavam emanações nocivas, invisíveis, provenientes de matéria orgânica em decomposição (cadáveres humanos e de animais, restos de alimentos, dejetos humanos, que eram encontrados em grande quantidade nos locais em que viviam), que corrompiam o ar, entravam pelas vias aéreas superiores e atacavam o corpo humano, gerando todas as doenças.

e manipulação sensorial); conversar com o doente (anamnese); entender o problema (raciocínio diagnóstico); e estabelecer procedimentos terapêuticos ou ações adequadas aos sinais e sintomas referidos (prognóstico). Essa prática dura até os nossos dias.

A relação do homem com o ambiente caracterizou o pensamento de Hipócrates e sua produção de conhecimento sobre a saúde-doença. Ele acreditava que esse fenômeno ocorria por desequilíbrio entre as quatro emanações fundamentais do corpo humano (os quatro humores): a bile amarela, a bile negra, o sangue e a linfa. Além disso, considerava também as influências do ar na produção de doenças e peste. É daí que surge a Teoria dos Miasmas, em que a ocorrência das doenças é explicada pelos maus odores advindos de lugares insalubres e fétidos, com matéria orgânica em decomposição, os quais interagiam com os homens e afetavam os corpos.

Mais à frente, o Império Romano assimilou as concepções dos gregos, sem avançar muito em relação às práticas curativas, mas desenvolvendo de forma magistral a engenharia sanitária e a administração pública. Criou aquedutos para suprir a necessidade de água para consumo humano, poços, cisternas de água de chuva, canalizações extensas, banheiros e fontes públicas, que beneficiaram grande parcela da população (ROSEN, 1994).

Os romanos, àquela época, já utilizavam banheiros públicos destinados a lugares pobres e degradados, onde as pessoas viviam aglomeradas

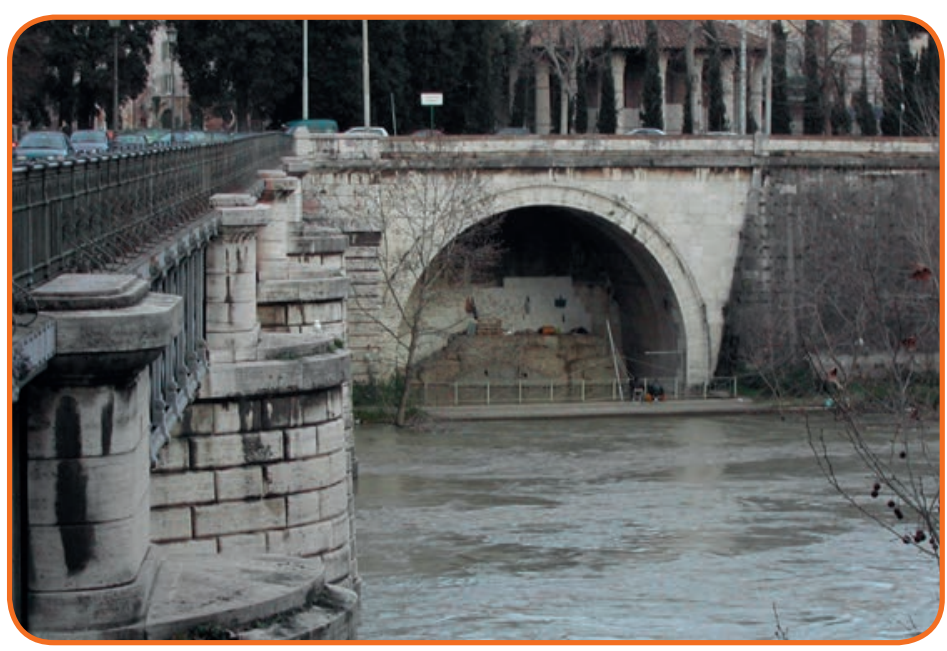

A Cloaca Máxima foi construída na antiga Roma, no final do século VI a.C., e funcionou como rede de esgoto, recebendo os dejetos da cidade e permitindo que fossem despejados no Rio Tibre, o qual, por sua vez, desemboca no mar. Nos dias de hoje, está desativada, mas a sua "boca" (a saída para o Tibre) ainda pode ser vista, embora esteja selada.

Fonte: Wikimedia Commons. em condições desumanas, anunciando os tempos terríveis que estavam por vir. Para sanar o problema de forma extensiva, criaram a Cloaca Máxima, principal sistema de esgoto de Roma, concebido e construído para drenar os pântanos e, depois, utilizado para coletar água de superfície e esgotos por meio de canalização.

Os romanos também se preocupavam com os problemas de saúde decorrentes dos diferentes ofícios. Por exemplo, os relacionados aos tocadores de flauta, que anunciavam pelos sons as boas-novas ou tragédias e, por tanto esforço repetido, ficavam com as mãos rígidas; aos mineiros e à ausência de ventilação nas 
minas, que os expunha a fluidos e vapores tóxicos. Vê-se, nesses fatos, o primeiro desenho do que hoje chamamos de vigilância à saúde do trabalhador.

\section{O período das trevas: a Idade Média - religiões, pestes e bárbaros}

A história do homem se constrói por conquistas e superações - de conhecimentos, práticas, culturas, sistemas políticos e econômicos. O surgimento do modo de produção feudal pôs por terra o Império Romano do Ocidente, em cerca de 476 d.C. Como consequência, provocou o enfraquecimento da cultura urbana e a decadência da organização e das práticas de saúde pública. Várias obras sanitárias foram destruídas por abandono e ausência de manutenção, e a organização do governo foi desmantelada (BATISTELLA, 2006; ROSEN, 1994).

Este período, chamado de Idade Média (5001500 d.C.), tem alguns movimentos característicos que o definem e situam como um tempo de trevas e sofrimentos, em função do surgimento de várias religiões e do poder inquisidor e punitivo da Igreja Católica para com os pobres e os diferentes; da ocorrência ininterrupta, por longo período, de pestes e epidemias que dizimaram populações; e da violência das invasões (bárbaras), que, semelhante à peste, destruiu culturas e usurpou territórios.

A religião predominante era o Cristianismo, trazendo consigo a noção de pecado como estratégia punitiva para todo aquele que ousasse desobedecer a seus credos e orientações. A saúde e a doença eram associa-

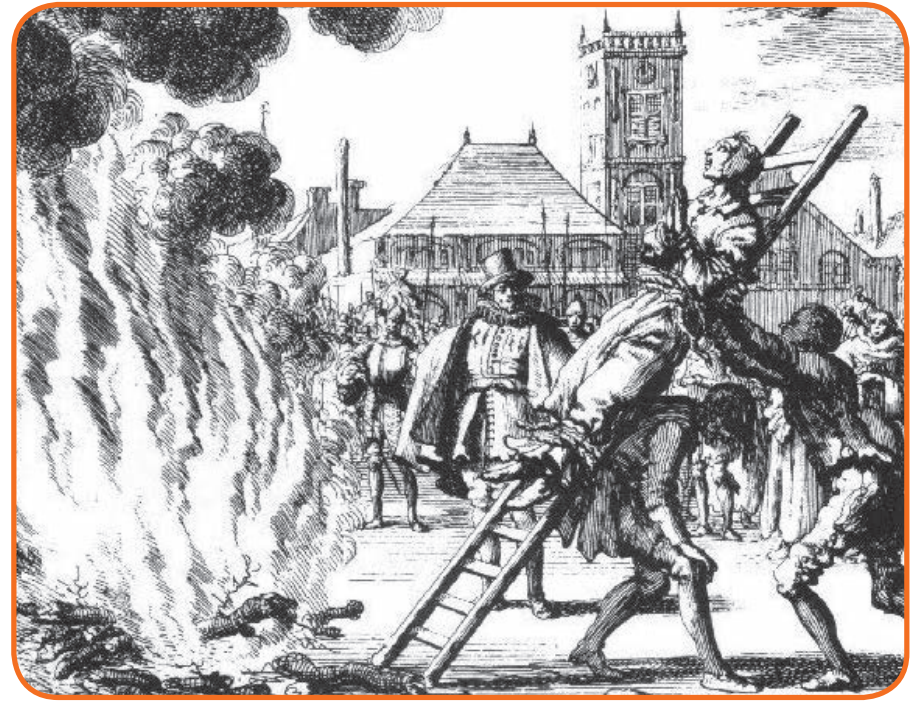

Suplício de Anneken Hendriks em Amsterdam, de Jan Luyken (1649-1712). $\mathrm{Na}$ Idade Média, a força da Igreja católica era tanta que aqueles que não se rendessem às determinações de suas práticas e crenças eram considerados hereges e queimados em fogueiras.

Fonte: Wikimedia Commons. das ao cumprimento ou descumprimento dos preceitos cristãos. O adoecimento decorria do pecado, castigo de Deus ou coisa do demônio. Portanto, para obter passagem para o céu, o dízimo (quantidade de dinheiro estabelecida pela Igreja) era a moeda de troca para o perdão e a vida eterna.

Nesse contexto, as práticas médicas greco-romanas de cura foram substituídas por ações de religiosos, como exorcismos, rezas, penitências, autoflagelação, unção, benções e invocação de santos para purificar a 
Morte Negra (2010) é um filme dirigido por Christopher Smith que aborda a Inglaterra na Baixa Idade Média. Assolada pela peste, a população se divide entre dois extremos. De um lado, há aqueles que acreditam, por força da Igreja, que a epidemia é castigo de Deus e que é necessário expiar os pecados por autoflagelação e queima das mulheres consideradas bruxas. Do outro lado, estão aqueles que passam a negar Deus (porque estava matando seus filhos e sendo vingativo) e a buscar outras divindades. Vale assistir! alma e estabelecer sintonia com o divino. Portanto, se os procedimentos religiosos para amenizar a doença não funcionassem, a morte era a liberdade e o caminho até Deus. Como consequência dessa visão, as práticas de cura deixaram de ser realizadas por médicos e passaram a ser atribuição de religiosos. Para o olhar do Catolicismo, impregnado de preconceitos, qualquer método racional que tentasse explicar o adoecimento e a morte, ou os relacionasse com os fenômenos da natureza, era tido como heresia e blasfêmia contra as Escrituras do Evangelho.

Os defensores de novas descobertas e métodos ditos profanos eram perseguidos, julgados e enforcados, ou queimados vivos. Há uma involução ou estagnação da medicina hipocrática nesse período; porém, os árabes e judeus conseguiram desenvolver estudos importantes relacionados à farmacologia e à cirurgia (SCLIAR, 2002).

Vivia-se a iminência constante de pestes que atemorizavam as populações. A lepra e a peste bubônica foram responsáveis pelo maior número de mortes, enquanto o sarampo, a varíola, a difteria, a influenza, o ergotismo e a tuberculose eram doenças comuns, acompanhadas de escabiose e erisipela. Para expiar os pecados expostos pela lepra, que consumia os corpos, era preciso isolar os doentes como forma de purificá-los, considerando-os mortos desde então. Por isso, todos tinham pavor de seus portadores e da ameaça que representavam. Já a peste bubônica, causada pela bactéria Yersinia pestis, transmitida por pulga de ratos, dizimou um quarto da população europeia no século XIV.

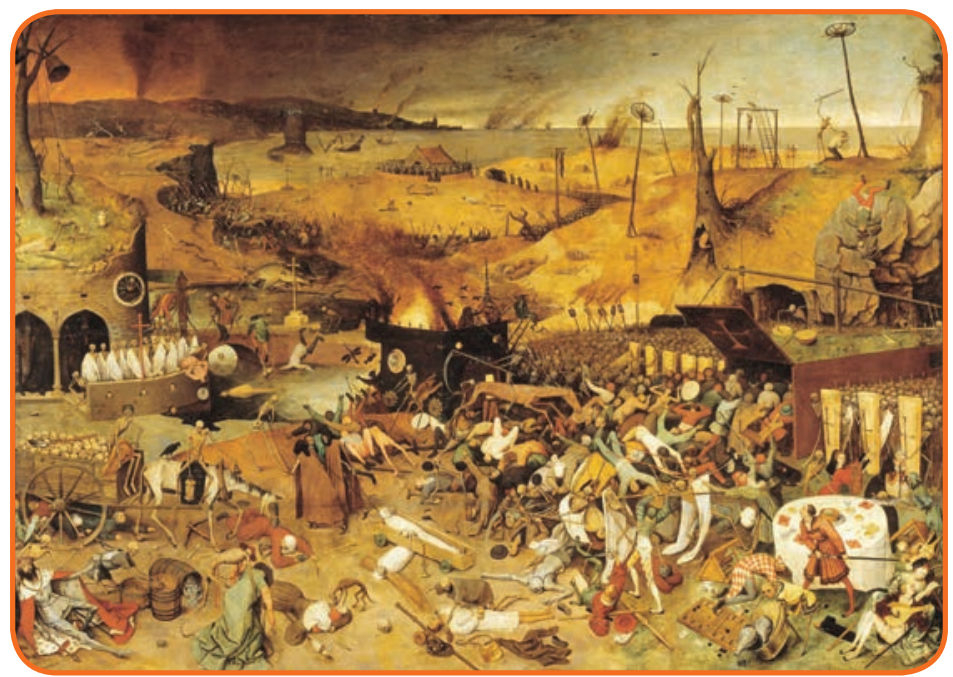

Triunfo da Morte (1562), de Pieter Bruegel, retrata uma cidade dizimada pela peste.

Fonte: Wikimedia Commons.
A disseminação da peste foi favorecida pelas grandes navegações, por guerras constantes, migrações, fome e miséria, condições urbanas degradantes, aumento da população nas cidades, ausência de higiene e promiscuidade - tudo isso contribuiu para firmar a imagem da vida medieval como o lugar da morte e das trevas. As ações de saúde pública para sanear os espaços públicos eram ineficazes diante do cenário de destruição e medo. A Idade Média sucumbiu em meio à escuridão do conhecimento, dando lugar à chegada de um novo tempo. Mesmo que a natureza transmissível de algumas doenças fosse cada vez mais nítida (como 
a lepra e a peste bubônica), a teoria miasmática ainda persistia como modelo explicativo.

Na Idade Média foram criados ou instituídos:

- Os primeiros códigos sanitários para ordenação e normatização de estabelecimentos de criação de animais, matadouros, desaguadouros, recolha de lixo, pavimentação de ruas e canalização de dejetos (ROSEN, 1994).

- Os primeiros hospitais de iniciativa da Igreja. Inicialmente para receber os pobres, os desvalidos e isolar os doentes e, depois, para controlar os corpos e deter os desviantes - um lugar de exclusão e estigma (FOUCAULT, 1982b, p. 99-100).

- As primeiras quarentenas, com a lepra. A prática de isolamento destinava-se a impedir a disseminação das doenças, tendo como explicação teórica a noção de doença comunicável (ROSEN, 1994).

\section{O século das luzes: ampliando o conhecimento sobre a natureza e a saúde}

A mesma Igreja que perseguiu as pessoas que não seguiam o seu credo - os hereges - abriu a possibilidade de se consolidar um conjunto de conhecimentos advindo da civilização greco-romana, que tinha, na natureza, a referência para compreensão da saúde e da doença.

Nos primeiros anos de 1500 se iniciou o Movimento Renascentista - a saída das trevas. Nessa época já se falava na possibilidade de a sífilis ser contraída por contato sexual, bem como de haver agentes específicos para cada doença. Essas hipóteses sobre a origem (etiologia) do adoecimento foram levantadas por um médico e também poeta, Girolano Fracastoro (1478-1553), que, mesmo sem ter um microscópio, conseguia imaginar a existência de seres minúsculos portadores de doenças e capazes de transmiti-las e contagiar as pessoas.

Enquanto o pensamento sobre a saúde e a doença se modificava a partir dos estudos de observação da natureza, também se transformava o modo de produzir a sobrevivência humana e a riqueza material. $\mathrm{O}$ regime feudal, baseado em atividades rurais, na posse da terra e na relação servo-senhor, foi substituído pelo comércio de produtos feitos à mão (manufatura) e sob o comando de um personagem - um negociante chamado burguês.

Alguns mosteiros desenvolveram, em seu interior, hábitos e instalações higiênicas como forma de preservar a saúde; essa foi uma das razões para que, no fim da Idade Média, eles abrigassem as primeiras universidades.

O microscópio só foi inventado no século XVII. 
O grande movimento do comércio e o desenvolvimento de áreas de conhecimento como agricultura, mineração, metalurgia e navegação impulsionaram o desejo do homem de ampliar seu horizonte comercial. Foram organizadas as primeiras navegações, cujos objetivos eram conquistar novos continentes, obter recursos e transmitir conhecimentos. Simultaneamente, criaram-se instituições acadêmicas, chamadas de universidades, para refletir sobre as descobertas e novos saberes.

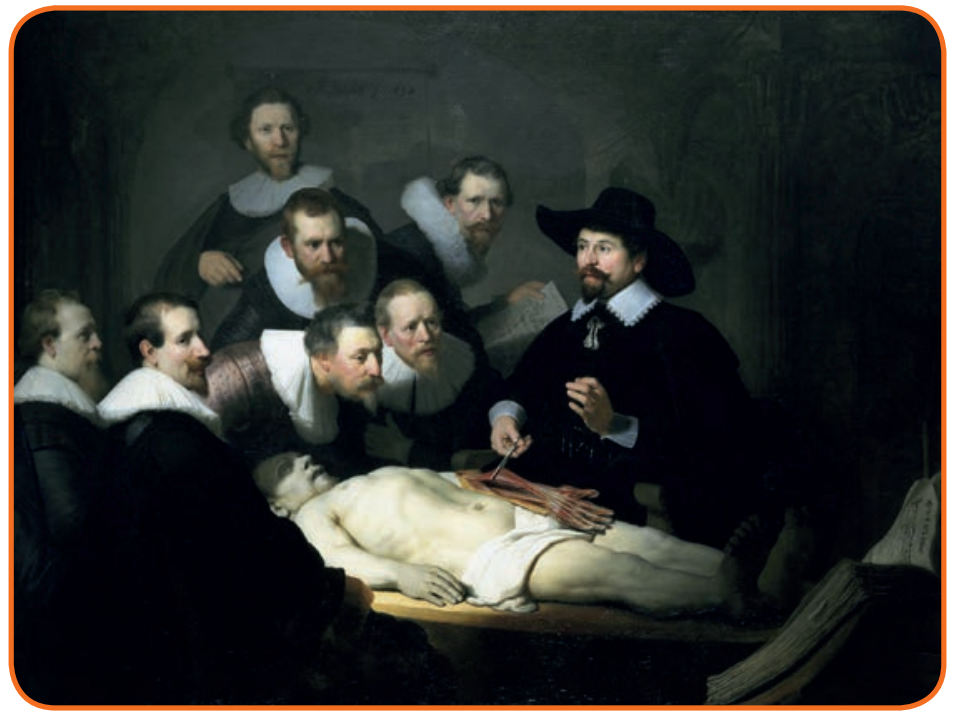

A Aula de Anatomia do Dr. Nicolaes Tulp, de Rembrandt (1606-1669). As artes, de uma maneira geral, viveram uma grande efervescência durante o Renascimento. Uma diferença em relação ao período anterior é que os artistas não se focavam mais na arte sacra somente, mas também em eventos cotidianos, como, no caso desta tela, uma aula de anatomia.

Fonte: Wikimedia Commons
Nesse período, foram desenvolvidos inúmeros estudos sobre fisiologia, anatomia e a descrição de doenças por meio da observação dos corpos e da epidemiologia. Esses conhecimentos possibilitaram aos humanistas pensar sobre o fenômeno do adoecimento e a ocorrência das epidemias. Formaram-se, então, dois grupos: um a favor da teoria do contágio - em que um agente ou uma causa explicava a ocorrência de cada doença -, e outro que defendia a teoria da constituição epidêmica, na qual as epidemias resultariam de desequilíbrios atmosférico e corporal. Essa polêmica durou séculos e impregnou o pensamento da saúde pública até os nossos dias (CZERESNIA, 1997).

A efervescência do Renascimento nos séculos XVI e XVII revalorizou o saber

técnico e ampliou as especulações na saúde, nas artes, na geometria, na matemática, entre outras disciplinas, contribuindo para se firmarem os alicerces da ciência moderna e do método científico. Porém, somente no fim do século XVIII, com o surgimento dos estudos de anatomia patológica, é que foi fundado o movimento da medicina moderna (FOUCAULT, 1980 apud BATISTELLA, 2006).

\section{Modernidade e descobertas: cidades, fábricas e a medicina social}

O comércio e o mercado tornaram as cidades lugares de troca e comercialização de mercadorias e, por consequência, o centro da vida das pessoas, aniquilando de vez o regime feudal. A produção, anteriormente artesanal, passou por uma drástica mudança com a invenção do motor a vapor para as máquinas: foi o advento da Revolução Industrial, 
que alterou os modos de produção e de relação do homem com a produção e o trabalho.

Em função da presença da fábrica e da máquina a vapor, algumas cidades foram elevadas a centros políticos e econômicos. Com a oferta de empregos nas fábricas e a força econômica das cidades, houve aumento de população, advinda da área rural. As condições de vida ficaram cada vez mais precárias em função da aglomeração de pessoas em habitações mínimas e da ausência de saneamento e higiene (HUBERMAN, 1981; SCLIAR, 2007).

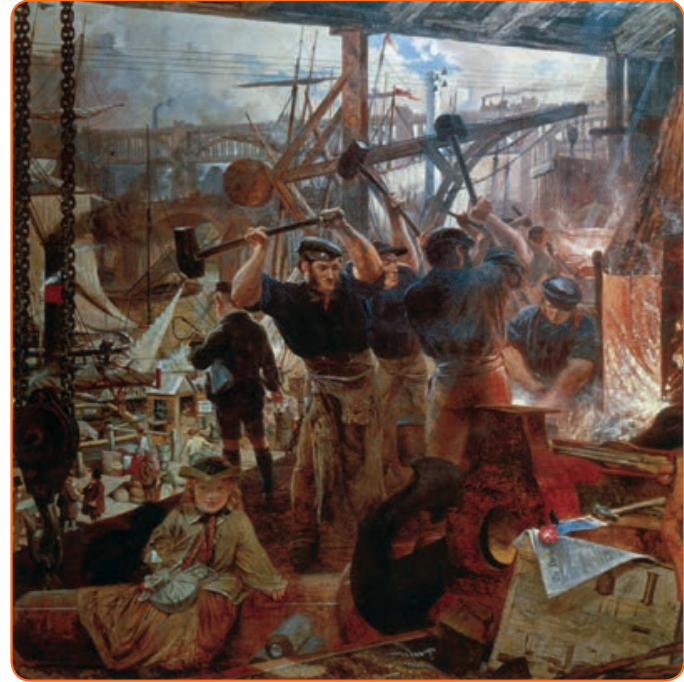

Ferro e Carvão, de William Bell Scott (1811-1890). Fonte: Wikimedia Commons.

\section{Relembrando}

Os hábitos culturais mantidos pelos habitantes das cidades medievais tornavam inócuas boa parte das medidas higienistas do Renascimento, que eram voltadas para limpeza dos lugares públicos, por não haver nenhuma ênfase na educação em saúde da população. O importante na Idade Média era afastar quem estava doente, e não havia a preocupação com medidas preventivas.

Pela primeira vez, na história da humanidade, o homem vendia sua força de trabalho em troca de pagamento, sendo explorado em jornada com mais de 16 horas diárias. Desse modo, para que não adoecesse, criaram-se as primeiras ações de proteção do trabalhador, com o objetivo de não parar a produção. O Estado aparece como instituição reguladora da cidade, da fábrica, da saúde e do trabalho, dessa forma influenciando a administração da saúde pública. Para consolidar seu poder, iniciou uma série de movimentos que foram desde a instituição de registros médicos até o saneamento das cidades. A partir desse momento, a saúde das populações passou a ser olhada pela medicina como dependente de questões sociais, culturais e econômicas (HUBERMAN, 1981; SCLIAR, 2007).

Pela necessidade de controle, já no início do século XVIII, alguns países criaram formas de regular a saúde e as doenças. Na Alemanha, surgiu a polícia médica como estrutura do Estado, que atuava na regulação da prática da medicina destinada a observar a morbidade. Na Inglaterra e na França, a preocupação foi com a cidade e os processos de adoecimento daí decorrentes - portanto, com a saúde urbana e a vigilância. Dava-se
Morbidade é uma variável característica dos seres vivos. Refere-se ao adoecimento ou ao conjunto dos indivíduos que adquirem doenças (ou determinadas doenças), num dado intervalo de tempo em uma determinada população. A morbidade mostra o comportamento das doenças e dos agravos à saúde na população (PEREIRA et al., 2004). 
Por áreas centrais da cidade, entendam-se cemitérios, mercados, espaços públicos, matadouros etc. ênfase ao controle do ar e da água e à observação das áreas centrais das cidades onde havia grandes aglomerados de pessoas, significando um perigo à saúde da população.

Na Inglaterra, por exemplo, foram instituídos a segunda Lei dos Pobres, o Ato da Fábrica e o Ato da Saúde Pública (Factory Act e o Public Health Act), promulgados, respectivamente, em 1833 e 1848. A Lei dos Pobres instituía a figura do comissário, que administrava a vida dos desvalidos, provendo auxílio e impedindo que o trabalhador da fábrica reivindicasse direitos. Também dava refúgio aos doentes e repudiados, gerenciando as instituições que estavam sendo constituídas e executavam a lei. Nos Atos se fazia a discriminação dessa população miserável que trabalhava nas fábricas, por meio de controle autoritário dos corpos (vacinação obrigatória) e cordão de isolamento ao acesso de lugares onde vivia a classe rica (HUBERMAN, 1981; SCLIAR, 2007).

Nesse contexto, passou-se a associar a causa das doenças a problemas vinculados às questões sociais, em especial às condições de vida da classe trabalhadora. Foram feitos alguns estudos sobre a classe trabalhadora e as condições de insalubridade das cidades, que deram suporte ao surgimento de uma teoria social da medicina, a qual afirma residirem nas condições de vida e trabalho do homem as causas das doenças (GUTIERREZ; OBERDIEK, 2001; JONES; MOON, 1987).

Na Inglaterra, a partir do século XIX, ocorreu a Reforma Sanitária, que teve como base o relatório de Edwin Chadwick: The Sanitary Conditions of the Labouring Population of Great Britain (Condições Sanitárias da População Trabalhadora da Grã-Bretanha), de 1842. Esse relatório apontava uma relação direta entre as deficiências das condições de vida das populações pobres (falta de abastecimento de água potável e esgoto, residências insalubres, coleta irregular de lixo) e as doenças, trazendo ônus à sociedade. Referia o medo e a possibilidade de revoltas populares em decorrência das más condições de trabalho e apontava a necessidade de os trabalhadores se manterem sadios e fortes para a indústria.

Alguns personagens dos séculos XVIII e XIX centrais para a saúde pública atual em razão de seus escritos e descobertas

- Louis René Villermé, médico, publicou em 1826 o relatório Tableau de I'état physique et moral des ouvriers, no qual, após analisar a mortalidade nos diferentes bairros de Paris, concluiu que esta era condicionada, sobretudo, pelo nível de renda da população.

- Willian Farr, médico, criou em 1839 os Relatórios anuais (Annual reports). Neles, os números de mortalidade se combinavam com vívidos relatos e 
chamaram a atenção para as desigualdades entre os distritos "sadios" e os "não sadios" do país.

- Edwin Chadwick, advogado, escreveu um relatório, em 1842, intitulado As condições sanitárias da população trabalhadora da Grã-Bretanha. Promulgou uma reforma com o Ato da Fábrica e o Ato da Saúde Pública (Factory Act e o Public Health Act), em 1833 e 1848, criando a Diretoria Geral de Saúde, encarregada de propor medidas de saúde pública e de recrutar médicos sanitaristas.

- Friedrich Engels, filósofo, escreveu o livro Condição da classe trabalhadora na Inglaterra, em 1845, no qual analisa a exploração dos trabalhadores que ocorria nas fábricas.

- Rudolf Virchow, patologista, em 1849, elaborou a teoria de doença epidêmica como uma manifestação de desajuste social e cultural.

É considerado o pai da medicina social.

- John Snow, médico, entre 1813 e 1858, demonstrou a associação entre elementos do ambiente e adoecimento e morte. Estudou a distribuição do cólera em Londres e comprovou que um poço que fornecia água à população era, de fato, uma fonte de contaminação. Escreveu o livro Os modos de transmissão do cólera. É considerado o pai da epidemiologia.

\section{A descoberta da bacteriologia: prevenção de doenças e a saúde pública}

O início do século XIX foi marcado por grande avanço da indústria e da vida urbana. No campo da saúde pública, os estudos traziam elementos associativos entre doenças e o ambiente social; porém, o instrumental disponível para comprovar a causalidade ainda era muito restrito, mesmo com as observações microscópicas de Antony Van Leeuwenhoek, no século XVII.

O uso do microscópio como suporte às especulações acerca das doenças infecciosas abriu a possibilidade de os cientistas conhecerem mais e melhor o comportamento dos pequenos germes causadores dessas enfermidades. Jacob Henle, em 1840, formulou a teoria dos organismos microscópicos vivos como causadores de doenças infecciosas. Esse foi o primeiro marco da era bacteriológica e da descoberta de vários parasitos.

No entanto, foram as descobertas do químico francês Louis Pasteur, no fim do século XIX, que reforçaram a existência e a participação de microrganismos específicos como fundamentais em determinados processos. Pasteur chegou a essa conclusão observando a fermentação de vinhos e cervejas com o auxílio do microscópio. 


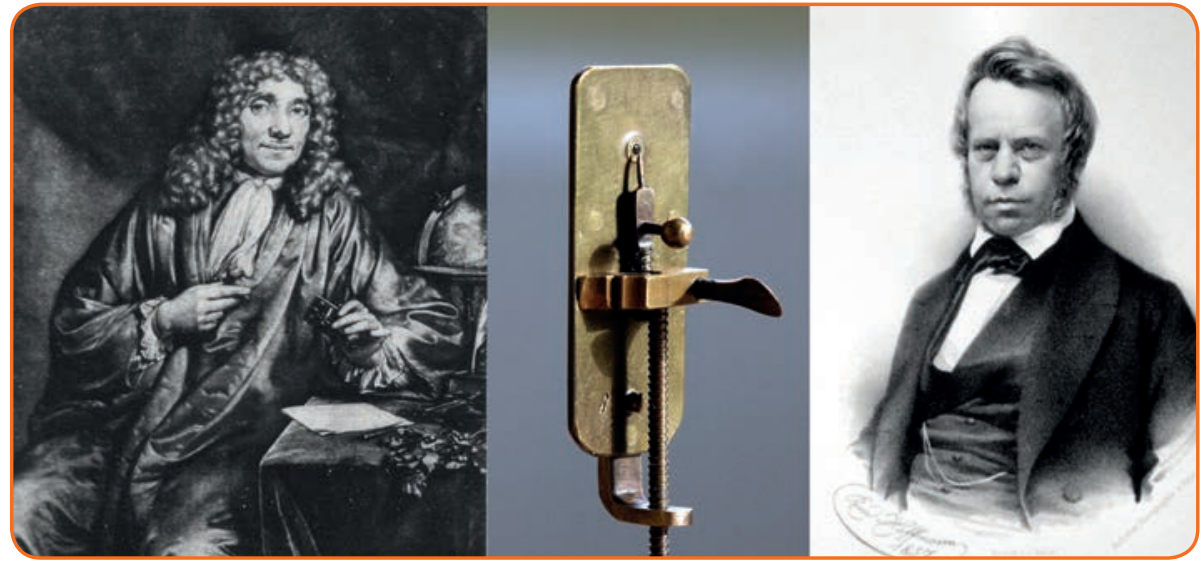

À esquerda, Leeuwenhoek, pai da microscopia. Ao centro, uma réplica de seu primeiro microscópio. Com esse instrumento bastante simples, ele conduziu vários estudos, entre eles o que mostrou a existência dos espermatozoides e de glóbulos vermelhos (ANTONY..., 2009). Na imagem à direita, Jacob Henle, um anatomista alemão importante pela descoberta de diversas estruturas do corpo humano (entre elas, a alça de Henle, no rim) e por ser o primeiro a formular uma teoria que reconhecia a existência de organismos não visíveis a olho nu capazes de causar doenças. Fonte: Wikimedia Commons.

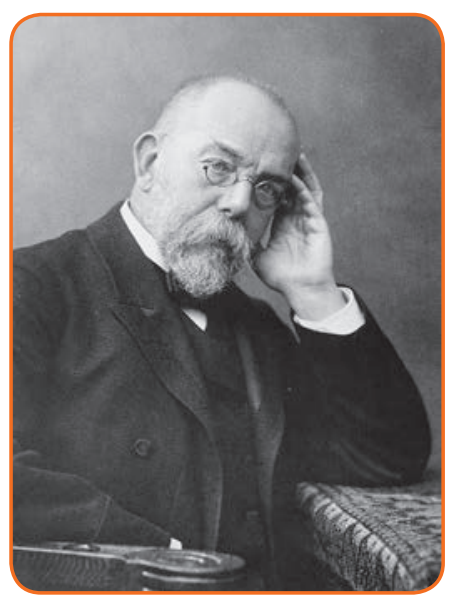

Robert Koch, por Wilhelm Fechner (1900).

Fonte: Wikimedia Commons

Princípio da imunidade ativa refere-se à inoculação de germes vivos em estado atenuado ou de seus extratos em um indivíduo.

Imunidade passiva refere-se à injeção, em uma pessoa, de anticorpos específicos produzidos em outro animal.
Pasteur tentou comprovar a participação de bactérias nos processos de adoecimento, porém sem obter êxito. Somente com o avanço das técnicas é que Robert Koch, em 1876, conseguiu associar um micro-organismo específico (um bacilo) a uma determinada doença (a tuberculose). Esse fato oferece elementos para responder a quase todas as questões relativas às doenças infecciosas, em especial as contagiosas, dando cientificidade a esse tempo.

Bem no início do século XX, ainda persistiam dúvidas sobre como ocorriam casos novos de uma doença sem que houvesse qualquer contato direto entre a pessoa sã e o indivíduo doente. Também causava inquietação ver pessoas expostas a outros doentes e que não adoeciam. Como resposta, foram reconhecidos a participação de hospedeiros intermediários na transmissão de doenças, os chamados vetores, e o papel dos portadores sadios na manutenção da cadeia epidemiológica (BANTA; DAHUCE, 1993; ROSEN, 1994).

A era bacteriológica possibilitou aplicar o princípio da imunidade ativa e passiva a todas as doenças infecciosas. Em seguida, foram produzidos vários soros e vacinas, para uma gama de doenças - febre amarela, poliomielite, febre tifoide, difteria, tétano, tuberculose, envenenamento por mordida de cobra, entre outros.

A crença na possibilidade de se erradicar as doenças infecciosas por meio de imunização estimulou a criação de laboratórios de microbiologia e imunologia em diversos países. Essas iniciativas, junto com o 
conhecimento sobre os modos de transmissão das doenças, o papel dos vetores nessa cadeia e as melhorias nas condições de vida das populações, propiciaram o declínio dos indicadores de mortalidade. A saúde pública começou a ter protagonismo nas ações de proteção e promoção da saúde.

Fato importante da era bacteriológica foi a descoberta da transmissão do cólera por John Snow, durante uma epidemia em Londres, no período de 1849 a 1854. Esse médico estudou a frequência (quantidade de casos por unidade de tempo) e a distribuição (no território) dos óbitos por cólera, fazendo um mapeamento destes e correlacionando-os com o tipo de água consumida pela população.

John Snow foi considerado o pai da epidemiologia. Conduziu inúmeras investigações no intuito de esclarecer a origem das epidemias de cólera em Londres.

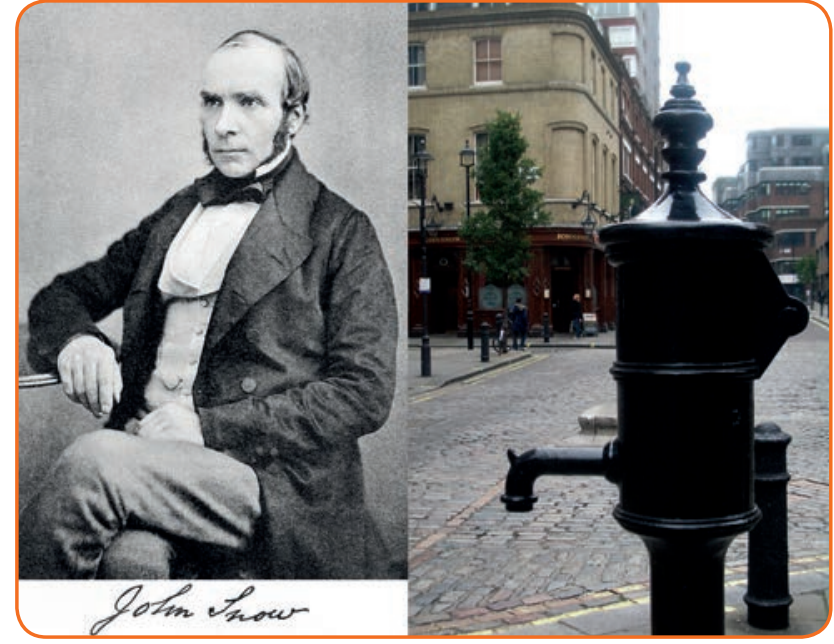

À esquerda, o epidemiologista John Snow e, à direita, o marco do poço que contaminou a população do Soho, em Londres, na epidemia de 1854.

Fonte: Wikimedia Commons.

\section{As teorias que sustentaram as concepções de saúde e doença}

A caminhada do ser humano ao longo do tempo tem sido marcada por grandes epidemias e descobertas, variadas crenças e visões de mundo, e novos conhecimentos, que ora complementam ora rompem com os anteriormente produzidos. Coerentes com essa trajetória, as concepções de saúde, doença e cuidado também evoluíram. Discutiremos a seguir as teorias que sustentaram essas concepções ao longo da história.

\section{Teoria unicausal ou unicausalidade}

Com o surgimento da bacteriologia, foi possível desvelar a origem de várias doenças e romper com as concepções que afirmavam serem os deuses, ou os ares fétidos, os responsáveis pelo adoecimento das pessoas - seja por castigo ou contaminação. Com isso, a Teoria dos Miasmas foi completamente suplantada.

No entanto, como tudo que é novo, na maioria das vezes, é imediatista, a descoberta dos microrganismos patogênicos ou germes reduziu 
o adoecimento a seus aspectos objetivos e mensuráveis, deixando de lado questões subjetivas importantes. Desse modo, pode-se dizer que a abordagem quantitativa dos fenômenos suplantou seus elementos qualitativos. Algumas disciplinas que seguiam essa orientação se desenvolveram bastante, como a farmacologia, a imunologia e a anatomia patológica.

Essa nova forma de pensar e observar a doença se apoiou em uma teoria que afirmava haver uma doença para cada agente ou patógeno, ou seja, uma única causa para cada agravo à saúde. Essa teoria foi chamada de unicausal ou linear. Só permitia a mediação de um vetor no caminho entre o agente ou patógeno e o indivíduo suscetível (Figura 1).

Figura 1 - Modelo unicausal

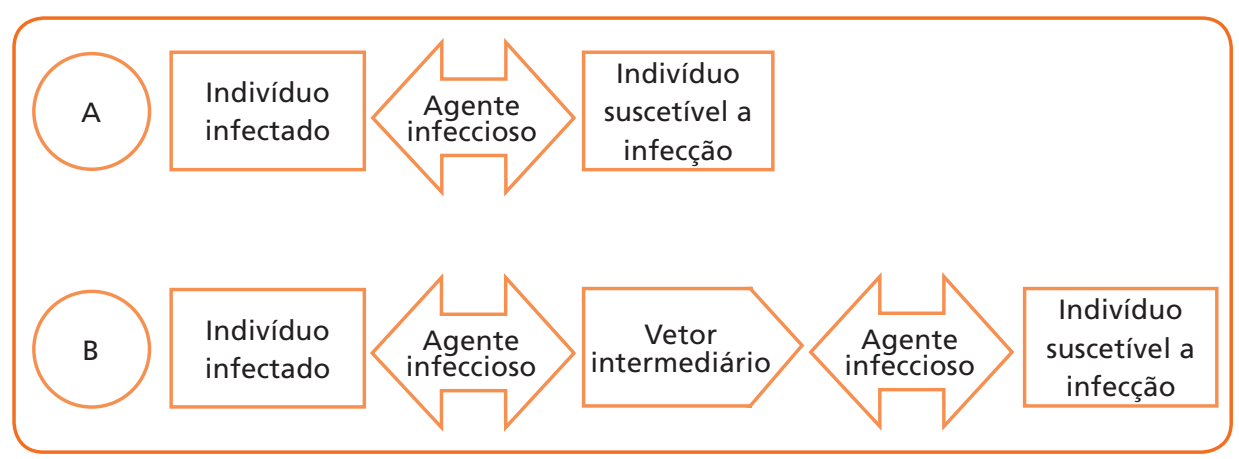

Na Situação A, a transmissão do agente infeccioso se dá diretamente do indivíduo infectado para outro indivíduo capaz de adquirir a doença - o indivíduo suscetível.

Na Situação B, a transmissão do agente infeccioso é mediada por um vetor (um mosquito, uma barata, um rato, um objeto perfurocortante, outros) do indivíduo infectado para outro indivíduo capaz de adquirir a doença - o indivíduo suscetível.

Fonte: Adaptado de Palmeira et al. (2004).

O modelo unicausal responde à visão positiva de ciência. Com as evidências que o microscópio e a bacteriologia trouxeram, a dimensão social da vida não é devidamente considerada para a compreensão do adoecer humano, deixando de lado as determinações econômicas, culturais e políticas. A medicina, nessa perspectiva, volta-se para as ações curativas, o biologicismo.

\section{Teoria multicausal ou multicausalidade}

Com a Segunda Guerra Mundial, a teoria unicausal se enfraquece, pois o processo de industrialização iniciado no século XIX, em países da Europa, proporcionou uma mudança nos padrões de adoecimento e morte das populações. Essa mudança no perfil epidemiológico foi chamada de transição epidemiológica. Nesse cenário, o modelo unicausal não conseguia mais explicar por completo a causa das doenças, 
principalmente aquelas decorrentes da urbanização e do desenvolvimento das cidades - as crônico-degenerativas, hoje denominadas não transmissíveis, que possuem diversos riscos a elas associados.

\section{O que entendemos por perfil epidemiológico?}

Refere-se a um conjunto de informações de saúde (indicadores e outros números) sobre o adoecimento e a morte de determinada população, em certo período de tempo. Permite articular um conjunto de causas, ou níveis de determinação, ligadas tanto às características dos indivíduos quanto às questões econômicas, sociais e políticas. Serve aos gestores, à equipe de saúde e aos demais tomadores de decisão para orientar suas ações e o planejamento em saúde. Representa a relação contraditória entre as condições de existência humana e os padrões de saúde-doença das populações (BREILH et al., 1990).

\section{O que entendemos por transição epidemiológica?}

O termo transição epidemiológica sugere mudanças ocorridas, principalmente durante o século XX, nos padrões de morbimortalidade da população mundial. Essas mudanças foram acompanhadas de um conjunto de transformações demográficas, sociais e econômicas (OMRAM, 2001; SANTOS-PRECIADO et al., 2003). O processo engloba três mudanças:

- substituição das doenças transmissíveis por doenças não transmissíveis (doenças crônico-degenerativas e de causas externas);

- aumento da expectativa de vida, tendo como consequência o envelhecimento da população, com a mudança de lugar do peso das doenças e mortes dos grupos mais jovens aos grupos mais idosos;

- transformação de uma situação em que predomina a mortalidade para outra, na qual a morbidade é dominante.

Essa abertura à interrogação sobre as causas das doenças propiciou o desenvolvimento de vários modelos para explicar a multiplicidade de elementos que podem contribuir para o adoecimento - os modelos multicausais. Algumas abordagens foram propostas para explicar o processo saúde-doença como forma de sintetizar o modelo de várias determinações, como, por exemplo, balança de Gordon; rede de causalidade de MacMahon; "pizzas" de causas componentes de Rothman; a tríade ecológica de Leavell e Clark (BARATA, 2005).

Alguns desses modelos são bastante simplificados, reduzindo a complexidade do processo saúde-doença a um conjunto de relações lineares entre variáveis, sem hierarquia de organização entre elas, sem considerar os efeitos de interação, oposição, sinergismo, potencialização etc.
Hierarquia significa que as variáveis seguem um ordenamento em função de sua maior ou menor contribuição para o adoecimento.

Interação representa a possibilidade de duas ou mais variáveis, ao se juntarem, produzirem um novo efeito diferente dos seus efeitos isolados para o adoecimento.

Oposição é a possibilidade de uma variável ter o efeito oposto ao da outra, ou ela mesma produzir efeitos opostos.

Sinergia significa a capacidade de uma variável se ajustar a outra, por seus efeitos semelhantes, somando seus efeitos.

Potencialização implica a capacidade de uma variável ampliar os efeitos de outra. 
Enfim, tratam as variáveis, ditas causais, como um conjunto de fatores independentes, cuja soma resulta em doença. Cada um desses fatores é visto como "condição ou atributo" de um dos elementos principais da tríade agente-hospedeiro-meio (BARATA, 2000).

\section{Modelo ecológico ou tríade ecológica}

A principal representação do modelo multicausal é a tríade ecológica, na qual, em cada vértice de um triângulo, há um elemento contribuinte para a saúde-doença.

Figura 2 - Tríade ecológica

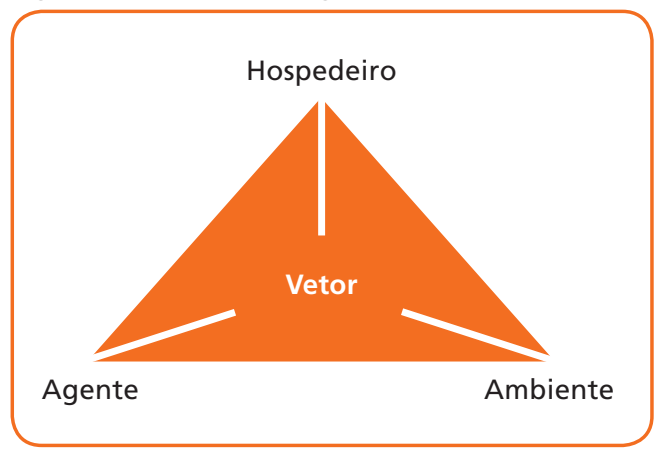

Fonte: Gordis (1996).
Esse esquema é a apresentação tradicional da causalidade das doenças transmissíveis, em que a doença é o resultado da interação entre o agente, o hospedeiro suscetível e o ambiente. Os agentes podem ser infecciosos ou não infecciosos e são necessários, mas nem sempre suficientes, para causar a doença. Os agentes não infecciosos podem ser químicos - substâncias - ou físicos.

Os fatores do hospedeiro são os que determinam a exposição de um indivíduo, sua suscetibilidade e capacidade de resposta. Tais fatores são influenciados por características como idade, grupo étnico, constituição genética, gênero, situação socioeconômica e estilo de vida. Por último, os fatores ambientais englobam os ambientes social, físico e biológico (BRASIL, 2009).

A tríade ecológica foi incorporada por dois autores, na década de 1970, para constituir outro modelo, que discutimos a seguir.

\section{Modelo da história natural das doenças (MHND)}

Proposto por Leavell e Clark (1976), o modelo da história natural das doenças (MHND) considera a interação, o relacionamento e o condicionamento dos três elementos fundamentais da tríade ecológica. É entendido como um conjunto de processos interativos que ocorrem entre o homem, o agente e o ambiente, produzindo o estímulo para o adoecimento. Essa interação acontece pela resposta do homem a esse estímulo e produz alterações que podem levar a um defeito, invalidez, recuperação ou morte. A doença seria resultante do desequilíbrio nas autorregulações existentes neste sistema.

Vamos entender o que Leavell e Clark (1976) quiseram representar em seu esquema explicativo sobre a história natural das doenças. O modelo está dividido em dois grandes momentos, que podem ser sequenciais: pré-patogênese e patogênese. Em cada um deles é possível intervir 
sobre a tríade ecológica (agente, hospedeiro e meio) com medidas preventivas adequadas.

Figura 3 - Modelo da história natural das doenças

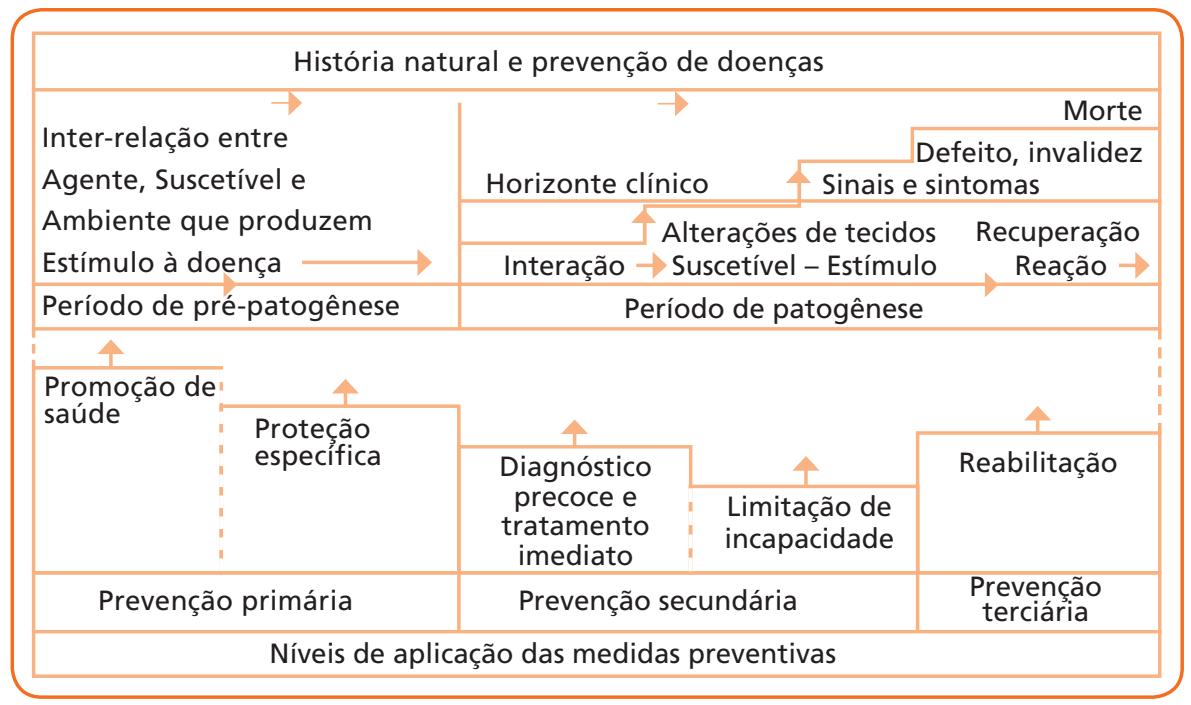

Fonte: Leavell e Clark (1976).

O período pré-patogênico, ou período anterior ao adoecimento, é o momento em que o homem está em um ambiente onde o agente patogênico ou infeccioso também se encontra. Por alguma razão (um estímulo), eles interagem, e há um desequilíbrio nessa relação - um dos dois elementos pode sofrer grandes mudanças. O agente pode morrer ou não causar nenhuma reação no hospedeiro (indivíduo suscetível), e o hospedeiro, por sua vez, pode abrigar o agente sem apresentar nenhuma manifestação de sua existência. Nesse período, é possível intervir na relação agente/hospedeiro com um conjunto de ações denominado prevenção primária. A prevenção primária consiste em estratégias para prevenir a exposição ao fator de risco. Podem ser ações de promoção (educação em saúde, alimentação saudável, exercícios físicos etc.) e proteção específica à saúde (imunização), de modo a inibir que os fatores e o próprio agente produzam o adoecimento.

Promoção da saúde é a principal ação da prevenção primária. Para a Organização Pan-Americana da Saúde (2010), é o somatório das ações da população, dos serviços de saúde, das autoridades sanitárias dirigido para o desenvolvimento de melhores condições de saúde individual e coletiva, que tem por objetivo prevenir fatores de risco. As ações específicas são: elaboração e implantação de políticas públicas saudáveis; criação de ambientes favoráveis à saúde; reforço da ação comunitária; desenvolvimento de habilidades pessoais; reorientação do sistema de saúde.
Medidas preventivas referem-se à prevenção, que pode ser entendida como "ação antecipada, baseada no conhecimento da história natural, a fim de tornar improvável o progresso posterior da doença" (LEAVELL; CLARK, 1976). 
As propostas de promoção da saúde em Leavell e Clark (1976) privilegiavam ações educativas normativas voltadas para indivíduos, famílias e grupos (BUSS, 2003). A medicina preventiva acabou por produzir uma redução dos aspectos sociais do processo saúde e doença, naturalizando-os ao construir modelos explicativos sem contextualização histórica do adoecer humano (AROUCA, 1975).
Nas doenças transmissíveis, período de latência é o período, na evolução clínica de uma doença, no qual os sintomas se manifestam e desaparecem, apesar de o hospedeiro ainda estar infectado e de já ter sofrido uma ou várias recaídas.

O período de incubação é o tempo que transcorre desde a entrada do agente infeccioso no hospedeiro até a apresentação dos sintomas.
O período patogênico, ou do adoecimento, é o momento em que ocorre um estímulo à interação do agente com o hospedeiro, gerando o adoecimento. Inicia-se o que chamamos de "horizonte clínico", em que o agente começa a produzir a doença no hospedeiro. Inicialmente, isso ocorre sem nenhuma manifestação externa (período de latência) e, em seguida, apresentam-se sinais e sintomas característicos daquele agente infeccioso, como uma resposta do hospedeiro aos efeitos danosos do agente.

No percurso da HND, a interação agente/hospedeiro pode produzir vários acontecimentos, tanto com relação ao hospedeiro quanto ao agente: a cura (o agente morre), o defeito ou dano (o agente morre, mas deixa sequelas no hospedeiro), uma condição crônica (o agente não morre e seus efeitos aparecem de tempos em tempos) ou a morte do hospedeiro junto com o agente. Nesse trajeto pode-se atuar de diferentes formas:

* Com prevenção secundária: no início do adoecimento, por meio de diagnóstico precoce, rastreamento e tratamento imediato, quando se detecta por meio de exames clínicos e diagnósticos a ação do agente; em fase mais avançada, quando já há danos causados pelo agente. Em cada um dos estágios, utilizam-se medidas terapêuticas adequadas a ele, tais como nutrição, medicamentos, cirurgia, radiação, exercícios.

* Com prevenção terciária: em estágio mais avançado, característico de um quadro crônico, quando o agente já causou danos permanentes ou se alojou no hospedeiro por longo tempo, utilizam-se medidas de prevenção terciária. Essas medidas envolvem a reabilitação com uso de vários métodos terapêuticos (promoção, medicamentos, radiações, exercícios, outros).

No entanto, se nenhuma ação de prevenção (primária, secundária e terciária) for suficiente e a interação agente/hospedeiro continuar, o hospedeiro pode chegar à morte.

A HND, embora importante no início do século XX, sofreu muitas críticas ao longo do tempo, por não explicar as doenças crônico-degenerativas, 
as mortes violentas e os acidentes produzidos pela modernidade. Outra crítica importante é que o modelo valoriza, dentre o conjunto de causas, as biológicas, deixando as sociais em segundo plano.

Nos anos 1960, após várias análises do modelo, propôs-se uma nova abordagem do processo saúde-doença que considerasse, nessa relação, a produção social e econômica da sociedade. Em outras palavras, um novo marco explicativo que aponta o papel da estrutura social como modeladora dos processos de produção da saúde ou doença.

\section{Modelo da produção social da saúde ou dos determinantes sociais da saúde}

Este modelo articula diferentes dimensões da vida em um processo permanente de interação. Nele, estão contemplados aspectos que explicitam as formas de viver de uma população, em uma realidade sanitária - um território:

* Aspectos históricos: mostram como as populações, ao longo do tempo, vão se organizando no espaço para construir suas condições de existência e produzir os territórios onde vivem; essa história vai falar do presente, do passado e ajudar a pensar o futuro.

* Aspectos econômicos: mostram os meios e as formas de produção da riqueza material das sociedades que influenciam nas formas de vida e na saúde individual e coletiva.

Aspectos sociais: mostram as relações sociais, como as pessoas interagem e se relacionam, criando seus códigos e sua linguagem para poder viver e se comunicar.

* Aspectos culturais: mostram como cada povo, cada sociedade, estabelece seus códigos e normas específicos, para poder viver e organizar a vida individual e coletiva.

* Aspectos biológicos: mostram que cada pessoa ou grupo específico tem características próprias que podem influenciar nas formas de viver, adoecer e morrer.

Aspectos ambientais: mostram que o lugar, o território e os elementos do ambiente têm influência na vida das pessoas, dependendo de como cada um se relaciona com eles.

* Aspectos psicológicos: mostram o quanto questões individuais relacionadas ao sentir e interpretar de cada pessoa podem influenciar sua vida e suas formas de adoecer. 

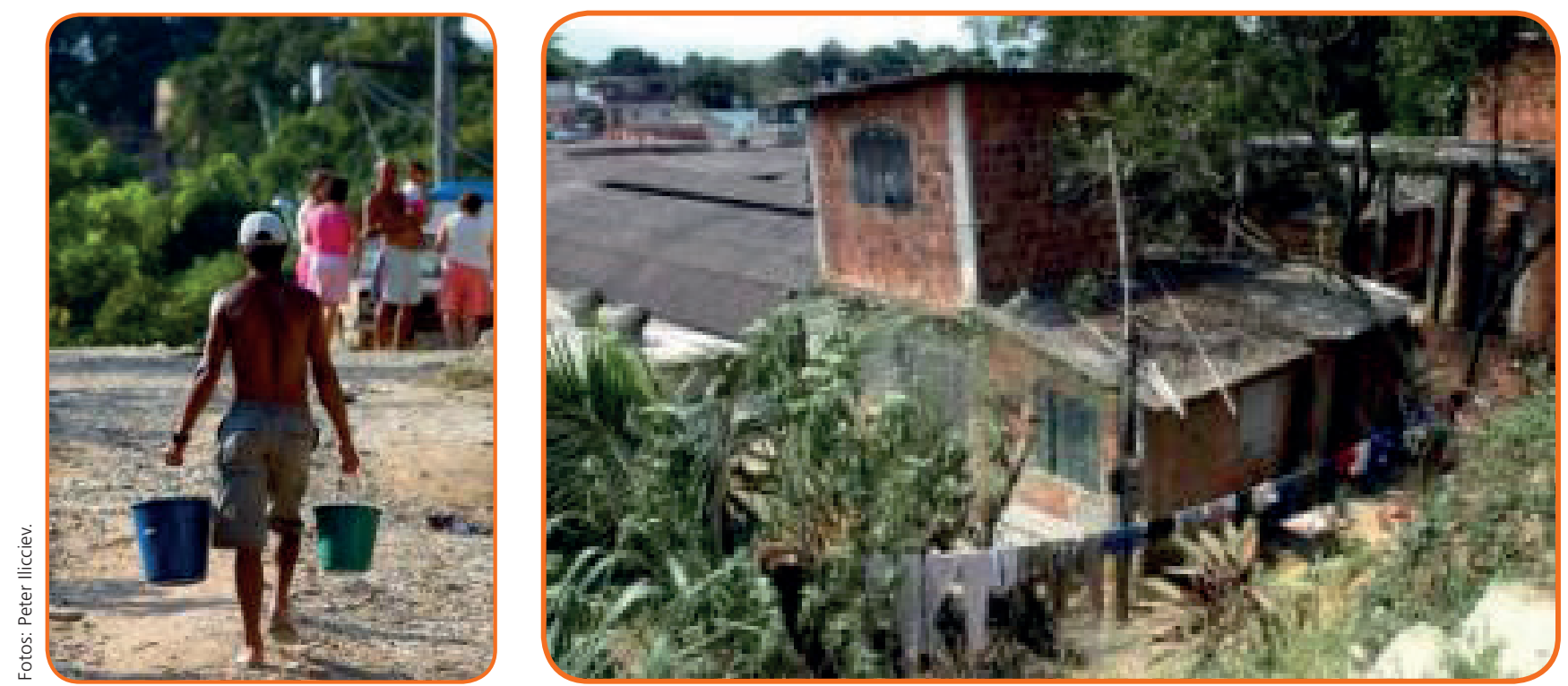

Longe de uma visão biologicista, o modelo da produção social da doença reconhece que as condições sociais, econômicas, ambientais e culturais, entre outras, têm influência sobre o estado saúde-doença das populações.

Fonte: Fiocruz Imagens.

Você verá em detalhes a discussão sobre determinantes sociais de saúde no Capítulo 3, "Introdução à vigilância em saúde: vigilância epidemiológica, vigilância sanitária, ambiental e saúde do trabalhador".
No processo de análise do modelo dos determinantes sociais da saúde (DSS), a noção de causalidade é substituída pela de determinação, em que há uma interligação hierárquica entre as condições próprias dos indivíduos e outras vinculadas à estrutura social para explicar a saúde e a doença. Essa forma de organizar o pensamento volta-se para a compreensão dos modos e estilos de vida, os quais estão na esfera das escolhas pessoais, como fatores culturais, afetos a práticas sociais, psicológicos e de constituição do ambiente.

De modo geral, compreendem-se os determinantes sociais da saúde como fatores sociais, econômicos, culturais, étnicos/raciais, psicológicos e comportamentais que influenciam a ocorrência de problemas de saúde e seus fatores de risco na população (BUSS; PELLEGRINI FILHO, 2007).

O modelo proposto por Dahlgren e Whitehead (Figura 4) é aceito em todo mundo e busca explicar o processo de determinação, o qual explicita a contribuição ou o peso de cada determinante para o adoecimento. Proposto em um arranjo em camadas, em que cada uma é sobreposta à outra, organiza-se em três conjuntos específicos de determinações, para as quais se vão requerer medidas de intervenção específicas:

*⿻一未丷 Determinantes proximais: são aqueles que estão mais ligados aos indivíduos (idade, sexo, características hereditárias). As medidas de prevenção e proteção são voltadas para o indivíduo ou grupos específicos de indivíduos. 
燐 Determinantes intermediários: são aqueles relacionados aos estilos de vida - individual e do grupo -, às relações comunitárias, à família e às redes sociais. As medidas de prevenção e proteção são voltadas para grupos específicos, para a comunidade, para mudança nas formas de viver e se organizar.

Figura 4 - Modelo dos determinantes sociais da saúde (DSS)

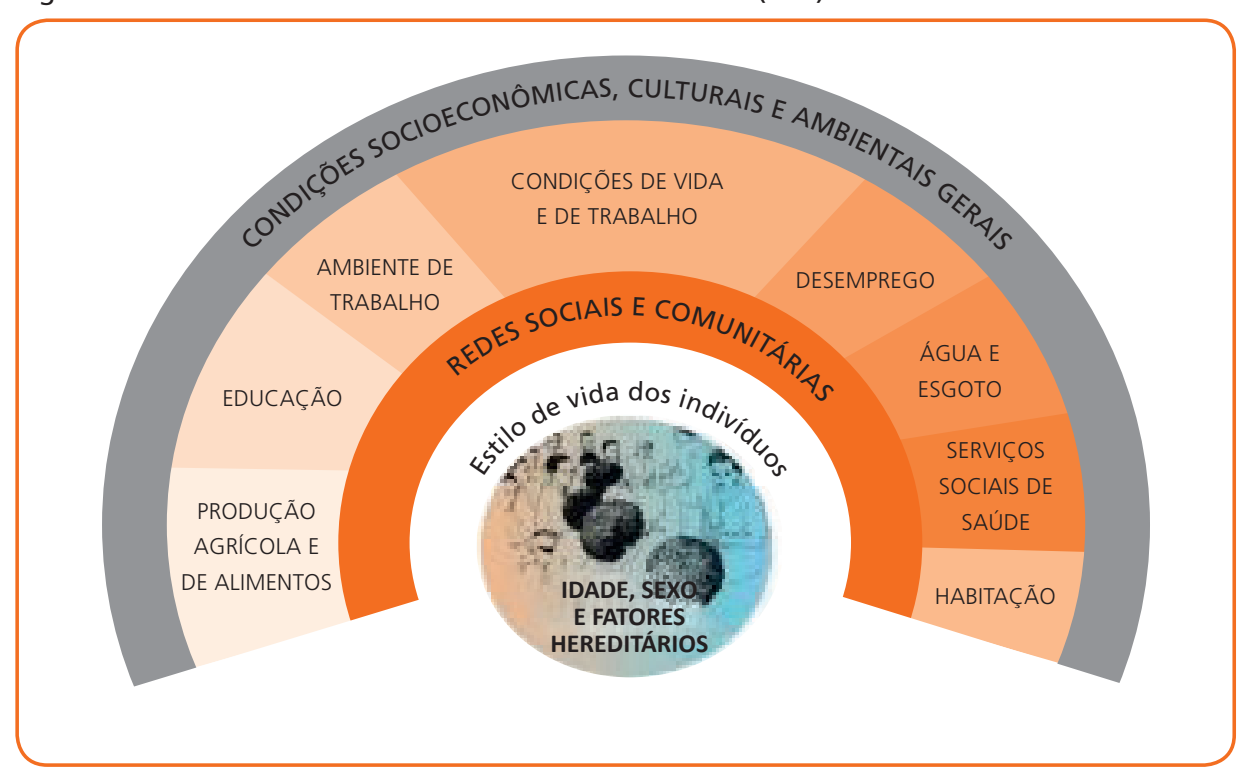

Fonte: Dahlgren e Whitehead (1991 apud COMISSÃO NACIONAL SOBRE DETERMINANTES SOCIAIS DA SAÚDE, 2008).

* Determinantes distais: são aqueles relacionados aos aspectos de condições de vida e trabalho e de condições socioeconômicas, culturais e ambientais gerais. As medidas de prevenção e proteção são relacionadas às ações mais globais voltadas para o coletivo, quase sempre organizadas por políticas sociais, programas e projetos de grande abrangência.

\section{Considerações finais}

Finalizando este capítulo, trazemos duas indagações que nos fizeram refletir ao longo de todo o percurso deste texto e que nos impulsiona a seguir pensando.

A doença é uma criação humana? E a saúde, a essência da própria vida?

Pensar a saúde e a doença e explicá-las a partir da nossa observação da natureza e dos nossos corpos tem sido, ao longo da história, um grande desafio para pesquisadores, cientistas e o homem comum. 
O fato é que estamos tão envolvidos com esses dois fenômenos que, por vezes, se torna muito difícil explicá-los com uma simples descrição - vamos ter sempre múltiplas interpretações. Cada pessoa ou grupo vai tentar explicá-los com base em seus referenciais teóricos, práticos e observacionais, buscando convencer o outro de que sua explicação é a mais adequada e correta.

Por essa razão, podemos compreender, ao longo do texto, as diferentes concepções de saúde, doença e cuidado que cada povo pôde organizar para poder sobreviver com "algo" que não conseguia explicar muito bem e evoluir em sua história.

Repare que cada povo, dependendo do conhecimento que acumulava, explicava a saúde, a doença e o cuidado com base no mundo em que vivia e com as ferramentas que possuía. Quando não tinha mais argumentos, recorria ao pensamento mágico para explicar o inexplicável.

Quantos cientistas ou pessoas de pensamento avançado para seu tempo foram vistos como loucos, hereges, bruxas ou pecadores só porque sugeriram ou formularam compreensões que não estavam de acordo com as normas do seu tempo?

Do mesmo modo, vimos que as teorias, os modelos explicativos e as concepções desse processo estiveram sempre evoluindo, avançando passo a passo, mas também deixando lacunas que, mais à frente, foram sendo preenchidas.

Pois bem, ainda hoje é assim. A vida humana é uma eterna descoberta, principalmente quando falamos de ciência, de conhecimento produzido. Sempre haverá uma relação entre o que já conhecemos e o que queremos conhecer, entre o que nos satisfaz e o que não mais nos interessa ou queremos experimentar.

Desse modo, para avançar no conhecimento, partimos de um saber existente, sobre o qual nos questionamos para continuar aprendendo, conhecendo. Sobretudo, vamos ter de nos perguntar sobre o que queremos conhecer e como vamos construir e buscar esse conhecimento.

Neste capítulo, a história da humanidade apresentou um conjunto de pensamentos e ideias que ainda hoje nos ajudam a compreender determinados problemas relacionados à saúde, à doença e ao cuidado. Mesmo na atualidade, vemos pessoas dizendo que estão doentes por castigo de Deus, ou que mandam benzer a criança para esta ficar boa do quebranto, ou do mau-olhado. 
Ao mesmo tempo, temos lado a lado tecnologias das mais simples às mais complexas, que nos protegem contra alguns fenômenos de saúde-doença que já conhecemos, como a paralisia infantil, o sarampo, a dengue, o tétano, a Aids e o diabetes, entre outros.

Diante dos fatos e do conhecimento humano acumulado, seria possível afirmar que a doença será sempre fruto de nossa experiência e explicação, e a saúde, fruto da nossa própria existência no mundo?

Para que você inicie o próximo capítulo e possa relacionar o que foi aprendido até agora com o que virá de novo, apresentamos o conceito atual de saúde, que dizemos ser "ampliado", em face de tudo que já produzimos de conhecimento sobre ele.

A saúde tem como fatores determinantes e condicionantes, entre outros, a alimentação, a moradia, o saneamento básico, o meio ambiente, o trabalho, a renda, a educação, o transporte, o lazer e o acesso aos bens e serviços essenciais; os níveis de saúde da população expressam a organização social e econômica do país. Diz respeito também à saúde as ações que se destinam a garantir às pessoas e à coletividade condições de bem-estar físico, mental e social (BRASIL, 1990).

Até os anos 1980 havia um entendimento de que a saúde seria a ausência de doença, ou um completo bem-estar físico, mental e social. Com a Constituição de 1988, o conceito de saúde mudou, e ela passou a ser entendida como resultado de um conjunto de necessidades satisfeitas, intimamente ligadas à vida cotidiana das pessoas.

\section{Referências}

ALMEIDA FILHO, N.; ROUQUAYROL, M. Z. Introdução à epidemiologia. 4. ed. rev. e ampl. Rio de Janeiro: Guanabara Koogan, 2006.

ALMEIDA FILHO, N. A ciência da saúde. São Paulo: Hucitec, 2000a.

ALMEIDA FILHO, N.O conceito de saúde: ponto cego da epidemiologia? Revista Brasileira de Epidemiologia, São Paulo, v. 3, n. 1-3, p. 4-20, 2000 b.

ALMEIDA FILHO, N.; ANDRADE, R. F. S. Holopatogênese: esboço de uma teoria geral de saúdedoença como base para a promoção da saúde. In: CZERESNIA, D.; FREITAS, C. M. (Org.). Promoção da saúde: conceitos, reflexões, tendências. Rio de Janeiro: Ed. Fiocruz, 2003.

ALMEIDA FILHO, N.; JUCÁ, V. Saúde como ausência de doença: crítica à teoria funcionalista de Christopher Boorse. Ciência e Saúde Coletiva, Rio de Janeiro, v. 7, n. 4, p. 879-889, 2002. 
ANTONY van Leeuwenhoek: inventor do microscópio. Jornal Brasileiro de Patologia e Medicina Laboratorial, Rio de Janeiro, v. 45, n. 2, abr. 2009. Disponível em: <http://goo.gl/JrC3se>. Acesso em: 18 jul. 2016.

AROUCA, A. S. S. O dilema preventivista: contribuição para a compreensão e crítica da medicina preventiva. 1975. Tese (Doutorado) - Faculdade de Ciências Médicas, Unicamp, Campinas, 1975.

BANTA, D.; DAHUCE, B.R. Health care technology and its assessment: an international perspective. Oxford: Oxford University Press, 1993.

BARATA, R. B. Epidemiologia social. Revista Brasileira de Epidemiologia, São Paulo, v. 8, n. 1, p. 7-17, 2005

BARATA, R. B.; BRICEÑO-LEÓN, R. E. (Org.). Doenças endêmicas: abordagens sociais, culturais e comportamentais. Rio de Janeiro: Ed. Fiocruz, 2000.

BATISTELLA, C. Abordagens contemporâneas do conceito de saúde. In: FONSECA, A. F.; CORBO, A. M. D. (Org.). O território e o processo saúde doença. Rio de Janeiro: Escola Politécnica de Saúde Joaquim Venâncio/Fiocruz, 2007. Disponível em: <http://www.epsjv.fiocruz.br/index.php?Area=Mat erial\&MNU=\&Tipo=8\&Num=24 $\geq$. Acesso em: 30 set. 2013.

BAZIN, G. Historia del arte: de la prehistoria a nuestros dias. Barcelona: Edicones Omega,1976.

BRASIL. Lei n. 8.080, de 19 de setembro de 1990. Dispõe sobre as condições para a promoção, proteção e recuperação da saúde, a organização e o funcionamento dos serviços correspondentes e dá outras providências. Diário Oficial da União, Brasília, DF, 20 set. 1990. Disponível em: <http://www. planalto.gov.br/ccivil_03/leis//8080.htm>. Acesso em: 12 set. 2015.

BRASIL. Ministério da Saúde. Secretaria de Vigilância em Saúde. Guia de vigilância epidemiológica. 7. ed. Brasília, DF, 2009.

BREILH. J. et al. Deterioro de la vida: un instrumento para análises de prioridades regionales en lo social y la salud. Quito: Corporación Editora Nacional/Ceas, 1990.

BURKE, P. Uma história social do conhecimento: de Gutenberg a Diderot. Rio de Janeiro: J. Zahar, 2003.

BUSS, P. M. Uma introdução ao conceito de promoção da saúde. In: CZERESNIA, D.; FREITAS, C. M. (Org.). Promoção da saúde: conceitos, reflexões, tendências. Rio de Janeiro: Ed. Fiocruz, 2003.

BUSS, P. M.; PELLEGRINI FILHO, A. A saúde e seus determinantes sociais. Physis: revista de saúde coletiva, Rio de Janeiro, v. 17, n. 1, p. 77-93, 2007.

CAPONI, S. Georges Canguilhem y el estatuto epistemológico del concepto de salud. História, Ciências e Saúde: Manguinhos, Rio de Janeiro, v. 4, n. 2, p. 287-307, jul./out. 1997.

CHALHOUB, S. Cidade febril: cortiços e epidemias na Corte Imperial. São Paulo: Companhia das Letras, 1996. 
COMISSÃO NACIONAL SOBRE DETERMINANTES SOCIAIS DA SAÚDE (Brasil). As causas Sociais das iniqüidades em saúde no Brasil: relatório final da... Rio de Janeiro, abr. 2008.

CZERESNIA, D. Ações de promoção à saúde e prevenção de doenças: o papel da ANS. [S.I.: s.n., 2003]. Trabalho elaborado para o Fórum de Saúde Suplementar, jul. 2003. Disponível em: <http:// www.ans.gov.br/portal/upload/biblioteca/tt_as_02_dczeresnia_acoespromocaosaude.pdf $>$. Acesso em: 30 set. 2013.

CZERESNIA, D. Do contágio à transmissão: ciência e cultura na gênese do conhecimento epidemiológico. Rio de Janeiro: Ed. Fiocruz, 1997.

CZERESNIA, D. O conceito de saúde e a diferença entre prevenção e promoção. In: CZERESNIA, D.; FREITAS, C. M. (Org.). Promoção da saúde: conceitos, reflexões, tendências. Rio de Janeiro: Ed. Fiocruz, 2003.

DIAMOND, J. Armas, germes e aço: os destinos das sociedades humanas. 3. ed. Rio de Janeiro: Record, 2002.

FOUCAULT, M. O nascimento da clínica. 2. ed. Rio de Janeiro: Forense-Universitária, 1980.

FOUCAULT, M. O nascimento da medicina social. In: FOUCAULT, M. Microfísica do poder. 3. ed. Rio de Janeiro: Graal, 1982a.

FOUCAULT, M. O nascimento do hospital. In: FOUCAULT, M. Microfísica do poder. 3. ed. Rio de Janeiro: Graal, 1982b. p. 99-100.

GONDIM, G. M. M. Do conceito de risco ao da precaução: entre determinismos e incertezas. In: FONSECA, Angélica Ferreira; CORBO, Ana Maria D’Andrea (Org.). O território e o processo saúdedoença. Rio de Janeiro: Escola Politécnica de Saúde Joaquim Venâncio/Fiocruz, 2007. cap. 3.

GORDIS, L. Epidemiology. Philadelphia: W. B. Saunders, 1996.

GUTIERREZ, P. R.; OBERDIEK, H. I. Concepções sobre a saúde e a doença. In: ANDRADE, S. M.; SOARES, D. A.; CORDONI JUNIOR, L. (Org.). Bases da saúde coletiva. Londrina: UEL, 2001.

HUBERMAN, L. História da riqueza do homem. Rio de Janeiro: Zahar, 1981.

JONES, K.; MOON, G. Health, disease, and society: a critical medical geography. Ed. ilustr., reimpr. London: Routledge \& Kegan Paul, 1987.

LEAVELL, S.; CLARK, E. G. Medicina preventiva. São Paulo: McGrawHill, 1976.

LEFEVRE, F.; LEFEVRE, A. M. C. Promoção de saúde: a negação da negação. Rio de Janeiro: Vieira e Vent, 2004.

LUZ, M. T. Saúde. In: DICIONÁRIO da educação profissional em saúde. Rio de Janeiro: Escola Politécnica de Saúde Joaquim Venâncio/Fiocruz, 2006. 
MEDRONHO, R. A. et al. Epidemiologia. 2. ed. São Paulo: Atheneu, 2009.

MINAYO, M. C. S. O desafio do conhecimento: pesquisa qualitativa em saúde. 8. ed. São Paulo: Hucitec, 2004.

OMRAM, A. R. The epidemiologic transition: a theory of the epidemiology of population change. Bulletin of the World Health Organization, v. 79, n. 2, p. 161-170, 2001.

ORGANIZAÇÃO PAN-AMERICANA DA SAÚDE. Módulos de princípios de epidemiologia para o controle de enfermidades: módulo 2: saúde e doença na população. Brasília, DF, 2010.

PALMEIRA, G. et al. Processo saúde doença e a produção social da saúde. In: BARCELLOS, C. (Org.). Informação e diagnóstico de situação. Rio de Janeiro: Escola Politécnica de Saúde Joaquim Venâncio/Fiocruz, 2004. (Série Material didático do Programa de Formação de Agentes Locais de Vigilância em Saúde - Proformar).

ROSEN, G. Uma história da saúde pública. São Paulo: Hucitec: Unesp; Rio de Janeiro: Abrasco, 1994.

ROSSI, P. Artes mecânicas e filosofia no século XVI. In: ROSSI, P. (Org.). Os filósofos e as máquinas. São Paulo: Companhia das Letras, 1989.

ROUQUAYROL, M. Z. História natural da doença e epidemiologia. In: ROUQUAYROL, M. Z.; ALMEIDA FILHO, N. Epidemiologia e saúde. 4. ed. Rio de Janeiro: MEDSI, 1993.

ROUQUAYROL, M. Z.; SILVA, M. G. C. Epidemiologia \& saúde. 7. ed. Rio de Janeiro: Medbook, 2013.

SANTOS, B. S. Um discurso sobre as ciências. 2. ed. São Paulo: Cortez, 2004.

SANTOS-PRECIADO, J. I. et al. 2003. La transición epidemiológica de las y los adolescentes em México. Salud Pública de México 45(supl 1):140-152.

SCHRAMM, J. M. A. et al. Transição epidemiológica e o estudo de carga de doença no Brasil. Ciência e Saúde Coletiva, Rio de Janeiro, v. 9, n. 4, Dec. 2004. Disponível em: <http://www.scielo. $\mathrm{br} / \mathrm{scielo}$.php?script=sci_arttext\&pid=S1413-81232004000400011\&lng=en\&nrm=iso>. Acesso em: 29 set. 2013

SCLIAR, M. Do mágico ao social: trajetória da saúde pública. São Paulo: Ed. Senac São Paulo, 2002.

SCLIAR, M. História do conceito de saúde. Physis: revista de saúde coletiva, Rio de Janeiro, v. 17, n. 1, p. 29-41, 2007.

SILVA, L. J. Considerações acerca dos fundamentos teóricos da explicação em epidemiologia. Revista de Saúde Pública, São Paulo, v. 19, p. 377-383, 1985.

SZKLO, M.; NIETO, J. Epidemiology: beyond the basics. 2nd. ed. Boston: Jones and Bartlett, 2007.

TEIXEIRA, C. F.; PAIM, J. S.; VILLAS BÔAS, A. L. (Org.). Promoção e vigilância da saúde. Salvador: ISC, 2002 